\title{
Proses untuk Menurunkan Konsentrasi Sianida Bebas dalam Air Limbah Pertambangan Emas Skala Kecil
}

\section{The Process to Reduce Free Cyanide Concentration in Wastewater from Small-Scale Gold Mining}

\author{
ASEP NUROHMAT MAJALIS*, SRI LUSIANI, YENI NOVITASARI
}

Pusat Teknologi Pengembangan Sumberdaya Mineral, BPPT

Gedung 820 Geostech, Kawasan Puspiptek Serpong, Tangerang Selatan Email: asepnurohmatmajalis@gmail.com

\begin{abstract}
The processing of gold by cyanidation has an impact on the release of free cyanide into the environment contained in the tailings. Free cyanide is very dangerous because it has very high toxicity. The process to remove free cyanide from tailings is the oxidation-precipitation using a mixture of sulfur and oxygen catalyzed by copper (II). This process can reduce the concentration of free cyanide as well as heavy metals. Free cyanide is oxidized to cyanate and heavy metals are deposited as metal-hydroxide. The optimum parameter of these methods on tailing cyanidation from gold ore Lebak Situ Village-Lebak Gedong District-Lebak Regency-Banten province are the ratio of the weight of $\mathrm{SO}_{2} / \mathrm{CN}$ - is 7; the catalyst dose is $75 \mathrm{mg} / \mathrm{L} ; \mathrm{pH}$ is 9 and the processing time is 4 hours. Application tests of the optimum parameter were able to reduce free cyanide concentration from $95.8 \mathrm{mg} / \mathrm{L}$ to $0.25 \mathrm{mg} / \mathrm{L}$. Wastewater from the processing with this process has fulfilled the specified Quality Standards. The wastewater pollution index value before the treatment process is 136.32 , changing to 0.36 after processing. These changes indicate that the oxidation-precipitation process has been able to change the condition of cyanidation wastewater from heavily polluted to better conditions.
\end{abstract}

Keywords: cyanidation, tailing, oxidation, optimum parameter, aplication test, pollution index

\begin{abstract}
ABSTRAK
Pengolahan emas dengan sianidasi berdampak pada pelepasan sianida bebas ke lingkungan yang terkandung di dalam tailing. Sianida bebas sangat berbahaya karena mempunyai toksisitas yang sangat tinggi. Salah satu proses untuk menghilangkan sianida bebas dari tailing adalah oksidasi-presipitasi menggunakan campuran gas sulfur dan oksigen terkatalisis tembaga (II). Proses ini mampu menurunkan konsentrasi sianida bebas sekaligus logam berat. Sianida bebas dioksidasi menjadi sianat dan logam berat diendapkan sebagai logam-hidroksida. Parameter optimum proses tersebut pada tailing sianidasi bijih emas Lebak Situ Kecamatan Lebak Gedong Kabupaten Lebak Provinsi Banten adalah rasio berat $\mathrm{SO}_{2} / \mathrm{CN}^{-} 7$; dosis katalis $75 \mathrm{mg} / \mathrm{L}$; pH pengolahan 9 dan waktu pengolahan 4 jam. Uji aplikasi parameter optimum tersebut mampu menurunkan konsentrasi sianida bebas dari 95,8 mg/L menjadi 0,25 mg/L. Air limbah hasil pengolahan dengan proses tersebut telah memenuhi Baku Mutu yang ditetapkan. Nilai indeks pencemaran air limbah sebelum proses pengolahan adalah 136,32 berubah menjadi 0,36 setelah dilakukan proses pengolahan. Perubahan tersebut menunjukkan bahwa proses oksidasi-presipitasi telah mampu mengubah kondisi air limbah sianidasi dari tercemar berat menjadi kondisi lebih baik.
\end{abstract}

Kata kunci: sianidasi, tailing, oksidasi, parameter optimum, uji aplikasi, indeks pencemaran

\section{PENDAHULUAN}

Pengolahan emas pada pertambangan emas skala kecil dengan proses sianidasi dapat berdampak negatif pada lingkungan khususnya perairan sebagai akibat lepasnya senyawa sianida yang bersifat toksik ${ }^{(1)}$. Senyawa sianida lepas ke lingkungan terutama bersamaan dengan pembuangan tailing. Toksisitas senyawa sianida yang ada di dalam tailing tersebut sangat tergantung pada spesinya. Toksisitas sianida bebas lebih tinggi dari weak acid dissociable cyanide $\left(\mathrm{CN}_{\text {WAD }}\right)$ dan toksisitas weak acid dissociable cyanide $\left(\mathrm{CN}_{\mathrm{WAD}}\right)$ lebih tinggi dari strong acid dissociable cyanide $\left(\mathrm{CN}_{\mathrm{SAD}}\right)^{(1)}$. Konsentrasi yang mematikan dari sianida bebas dimana $50 \%$ populasi ikan mati setelah terpapar 96 jam ( $\left.L C_{50} 96 h\right)$ adalah $0,05-0,18 \mathrm{mg} / \mathrm{L}^{(2)}$. Paparan sianida melalui pernapasan sebagai gas HCN pada konsentrasi 100-300 ppm dapat 
mengakibatkan kematian dalam waktu 10-60 menit dan pada konsentrasi 2000 ppm dapat mengakibatkan kematian dalam waktu satu menit. Dosis mematikan dimana $50 \%$ biota mati $\left(L D_{50}\right)$ sianida melalui proses pencernaan adalah 1-3 $\mathrm{mg} / \mathrm{kg}$ berat badan yang dihitung sebagai hidrogen sianida ${ }^{(3)}$. Oleh karena itu, senyawa sianida khususnya spesi sianida bebas pada tailing proses sianidasi bijih emas perlu dihilangkan terlebih dahulu sebelum dilepas ke lingkungan.

Beberapa proses untuk menurunkan konsentrasi sianida bebas dalam air limbah telah banyak dikaji oleh para peneliti ${ }^{(4,5,6,7,8,9)}$. Prosesproses tersebut diantaranya adalah pengasaman (acidification) $^{(4)}$, klorinasi basa (alkaline chlorination), oksidasi kimia, pertukaran ion, penguraian secara alami (natural degradation), penguraian menggunakan mikroorganisme, evaporasi, dan adsorpsi ${ }^{(2)}$. Pemilihan prosesproses tersebut didasarkan pada faktor-faktor spesifik, diantaranya volume atau jumlah sianida, biaya pengolahan dan komposisi senyawa sianida yang akan diolah ${ }^{(5)}$.

Upaya untuk menurunkan konsentrasi sianida bebas melalui proses oksidasi-presipitasi menggunakan campuran gas sulfur dan oksigen serta tembaga (II) sebagai katalis telah diaplikasikan pada pertambangan emas skala besar di dunia ${ }^{(2)}$.. Proses tersebut secara selektif mengoksidasi spesi sianida bebas dan kompleks sianida lemah ( $\left.\mathrm{CN}_{\mathrm{WAD}}\right)$ menjadi sianat $\left(\mathrm{CNO}^{-}\right.$ $(10,11)$. Sianat memiliki toksisitas $1 / 1000$ kali sianida bebas ${ }^{(3)}$. Namun demikian, informasi aplikasi proses tersebut pada pertambangan emas skala kecil masih terbatas

Tabel 1. Hasil aplikasi penghilangan sianida bebas pada beberapa tambang di dunia dengan proses $\mathrm{SO}_{2} /$ udara $\left(\mathrm{O}_{2}\right)$ terkatalis tembaga ${ }^{(13)}$.

\begin{tabular}{lcc}
\hline \multirow{2}{*}{ Pertambangan } & Konsentrasi sianida $(\mathbf{m g} / \mathbf{L})$ \\
\cline { 2 - 3 } & Sebelum & Setalah \\
\hline Colosseum & 364 & 0,4 \\
\hline Ketza River & 150 & 5 \\
\hline Equity & 175 & 2,3 \\
\hline Casa Berardi & 150 & 1 \\
\hline Weatmin Premiere & 150 & $<0,2$ \\
\hline Golden Bear & 205 & 0,3 \\
\hline McBean & 370 & 0,2 \\
\hline Lynngold & 106 & 0,6 \\
\hline Mineral Hill & 350 & 0,5 \\
\hline Lac Shortt & 10 & 0,5 \\
\hline Citadel & 350 & 5 \\
\hline St. Andrew & 15 & 1 \\
\hline
\end{tabular}

Upaya untuk menurunkan konsentrasi sianida dengan proses ini mempunyai beberapa kelebihan dibandingkan dengan proses atau metode lain. Kelebihan tersebut adalah: (1) sumber gas sulfur yang digunakan mudah diperoleh karena dapat berasal dari proses roasting bijih yang mengandung sulfida atau dari sumber lain seperti sodium bisulfit, sodium metabisulfit. Namun yang paling banyak digunakan adalah sodium metabisulfit ${ }^{(12)}$. (2) pengoperasiannya mudah karena pengolahannya dapat dilakukan di dalam tangki reaktor pelindian sianidasi, (3) efektif mereduksi sianida bebas dalam fasa cair maupun fasa padatan, (4) mampu mengendapkan logamlogam yang ada dalam tailing, (5) waktu yang diperlukan relatif singkat, dan (5) secara ekonomi cukup efisien $^{(3)}$.

Persamaan reaksi oksidasi sianida oleh campuran gas sulfur dan oksigen terkatalisis tembaga (II) serta proses netralisasi dan pengendapan atau presipitasi logamnya disajikan di dalam reaksi (1), (2) dan (3) $)^{(3)}$.

$$
\begin{gathered}
\mathrm{C}_{\mathrm{WAD}(\mathrm{aq})}^{-}+\mathrm{O}_{2(\mathrm{~g})}+\mathrm{SO}_{2(\mathrm{~g})}+\mathrm{Cu}^{2+}{ }_{(\mathrm{aq})}+\mathrm{H}_{2} \mathrm{O}_{(\mathrm{l})} \rightarrow \\
\mathrm{CNO}_{(\mathrm{aq})}+\mathrm{Cu}^{2+}{ }_{(\mathrm{aq})}+\mathrm{H}_{2} \mathrm{SO}_{4(\mathrm{aq})} \ldots \ldots \ldots \ldots \\
\mathrm{H}_{2} \mathrm{SO}_{4(\mathrm{aq})}+\mathrm{Ca}(\mathrm{OH})_{2(\mathrm{aq})} \rightarrow \mathrm{CaSO}_{4(\mathrm{aq})}+2 \mathrm{H}_{2} \mathrm{O}_{(\mathrm{l})} . \\
\mathrm{Me}_{(\mathrm{aq})}+\mathrm{Ca}(\mathrm{OH})_{2(\mathrm{aq})} \rightarrow \mathrm{Me}(\mathrm{OH})_{2(\mathrm{~s})}+\mathrm{Ca}^{2+}{ }_{\mathrm{aq})} \cdot \text { (3) }
\end{gathered}
$$

Berdasarkan reaksi (1), (2) dan (3) tersebut, maka faktor-faktor yang mempengaruhi proses penghilangan senyawa sianida menggunakan campuran gas sulfur dan oksigen terkatalisis tembaga (II) adalah: rasio $\mathrm{SO}_{2} / \mathrm{CN}^{-}$, kelarutan oksigen, konsentrasi katalis tembaga (II) dan $\mathrm{pH}$ pengolahan. Secara stoikiometri rasio berat $\mathrm{SO}_{2}$ terhadap $\mathrm{CN}^{-}$teroksidasi adalah $2,46^{(3)}$. $\mathrm{CN}^{-}$ teroksidasi yang dimaksud adalah sianida yang mudah terdisosiasi yang meliputi sianida bebas dan kompleks sianida lemah $\left(\mathrm{CN}_{\text {WAD }}^{-}\right)$). Kebutuhan gas $\mathrm{SO}_{2}$ untuk proses disediakan dalam berbagai bentuk seperti gas $\mathrm{SO}_{2}$, natrium metabisulfit yang dikenal dengan nama dagang SMBS (sodium meta bisulfite) atau proses roasting bijih yang mengandung sulfur. Natrium sulfit dan natrium metabisulfit adalah yang sering digunakan saat ini. Jumlah tembaga (II) yang dibutuhkan untuk mengkatalisis reaksi bervareasi dan tergantung pada konsentrasi konstituen dalam limbah. Tembaga yang dibutuhkan akan berkurang secara signifikan untuk limbah yang mengandung lebih dari $50 \mathrm{mg} / \mathrm{L} \mathrm{Cu}^{(3)}$. Kondisi $\mathrm{pH}$ yang diperlukan ada pada rentang $\mathrm{pH} 7-10^{(13)}$ atau $\mathrm{pH} 8-10^{(3)}$. Selain parameter-parameter tersebut, parameter lain yang juga berpengaruh adalah waktu reaksi, temperatur dan pengadukan.

Penelitian ini bertujuan untuk menurunkan konsentrasi sianida bebas dalam air limbah pengolahan emas dari lokasi pertambangan emas skala kecil (PESK) Lebak Gedong Kabupaten Lebak Provinsi Banten dengan menggunakan campuran gas belerang dan oksigen serta katalis tembaga (II) pada kondisi batch skala laboratorium. Faktor-faktor yang 
berpengaruh yaitu rasio $\mathrm{SO}_{2} / \mathrm{CN}^{-}$(w/w), dosis katalis $\mathrm{Cu}$ (II), pH dan waktu telah diteliti. Kondisi optimum parameter operasi pengolahan yang telah diperoleh telah diaplikasikan pada skala yang lebih besar. Perbandingan kualitas air limbah sebelum dan setelah proses pengolahan pada uji aplikasi dianalisis dengan metode indeks pencemaran.

\section{BAHAN DAN METODE}

\subsection{Alat dan Bahan}

Alat-alat yang digunakan pada proses uji optimasi yaitu: reaktor gelas bervolume 4 liter sebagai tempat proses penghilangan sianida, agitator IKA RW 20 sebagai alat untuk proses pengadukan, dua (2) buah aerator untuk mensuplai oksigen ke dalam reaktor. Alat-alat yang digunakan pada proses uji aplikasi yaitu: reaktor SS-316 bervolume 32 liter yang dilengkapi dengan satu agitator yang dapat diatur kecepatan putarannya serta dua buah aerator.

Peralatan untuk analisis dan pengukuran yaitu $\mathrm{pH}$ meter Hanna HI83141 untuk mengukur pH slurry, DO meter Lutron DO-5509 untuk mengukur kelarutan oksigen di dalam slurry, spektrofotometer Hach 2010 untuk analisa konsentrasi sianida bebas yang ada dalam fasa cair tailing, dan alat-alat gelas serta plastik lainnya yang diperlukan.

Bahan yang digunakan meliputi: limbah berupa tailing proses sianiasi bijih emas dari lokasi Desa Lebak Situ Kecamatan Lebak Gedong Kabupaten Lebak Provinsi Banten, aquades, sodium metabisulfit $\left(\mathrm{Na}_{2} \mathrm{~S}_{2} \mathrm{O}_{5}\right)$ 99,9\%, $\mathrm{CuSO}_{4} .5 \mathrm{H}_{2} \mathrm{O} 99,9 \%, \mathrm{NaOH} 1,5 \mathrm{M}$, asam sulfat $0,1 \mathrm{M}$, cyaniver 3 , cyaniver 4 dan cyaniver 5 .

\subsection{Prosedur Kerja dan Pengumpulan Data}

\subsubsection{Optimasi Proses}

Optimasi proses pengolahan dilakukan untuk memperoleh parameter-parameter optimum dalam menurunkan konsentrasi sianida bebas dalam limbah. Parameter-parameter yang dimaksud adalah $\mathrm{pH}$ pengolahan, rasio berat $\mathrm{SO}_{2} / \mathrm{CN}^{-}$, konsentrasi katalis dan waktu pengolahan.

Disiapkan tailing proses sianidasi bijih emas pertambangan emas skala kecil dari lokasi Desa Lebak Situ Kecamatan Lebak Gedong Kabupaten Lebak Provinsi Banten, kemudian dikondisikan $\mathrm{pH}$ pada 12 dengan penambahan $\mathrm{NaOH}$ selanjutnya dihomogenisasi menggunakan agitator IKA RW 20 selama $1 / 2$ jam pada 500 rpm. Tailing yang telah dipreparasi diambil sampelnya untuk dianalisis konsentrasi sianida bebas awalnya. Ditimbang kebutuhan $\mathrm{Na}_{2} \mathrm{~S}_{2} \mathrm{O}_{5}$ (SMBS) dan $\mathrm{CuSO}_{4} .5 \mathrm{H}_{2} \mathrm{O}$ untuk volume limbah 1 liter. Tailing dimasukkan ke dalam reaktor gelas 4 liter yang telah dirangkai dengan agitator IKA RW 20 dan 2 buah aerator serta 1 buah detektor gas $\mathrm{HCN}$. Reaktor dihidupkan, dimasukkan katalis $\mathrm{Cu}$ dan $\mathrm{Na}_{2} \mathrm{~S}_{2} \mathrm{O}_{5}$ yang telah ditimbang, selanjutnya proses pengolahan dilakukan pada $\mathrm{pH}$, waktu reaksi, konsentrasi katalis $\mathrm{Cu}(\mathrm{II})$ dan rasio $\mathrm{SO}_{2} / \mathrm{CN}^{-}$yang ditetapkan. Setelah proses pengolahan selesai, tailing hasil pengolahan diambil sampelnya untuk dianalisa konsentrasi sianida bebas akhir.

\subsubsection{Uji aplikasi}

Disiapkan 20 liter limbah/tailing proses sianidasi bijih emas pertambangan emas skala kecil dari lokasi Desa Lebak Situ Kecamatan Lebak Gedong Kabupaten Lebak Provinsi Banten kemudian disampling hingga diperoleh $1000 \mathrm{ml}$ tailing. Sampel selanjutnya disentrifugasi dan disaring. Air limbah hasil penyaringan atau fasa cair tailing kemudian dipreparasi untuk analisis sianida bebas, $\mathrm{CN}_{\mathrm{WAD}}$, sianida total dan logam berat. Sampel untuk analisa sianida bebas, CN WAD dan sianida total dikondisikan pada $\mathrm{pH}>12$. Sampel untuk analisa logam berat dikondisikan pada $\mathrm{pH}<2$. Sampel yang telah dikondisikan pada $\mathrm{pH}>12$ sebagian diambil untuk dianalisis konsentrasi awal sianida bebasnya. Fasa padat tailing yang diperoeh dari proses sentrifugasi dikumpulkan untuk kebutuhan analisis sianida bebas, $\mathrm{CN}_{\text {WAD }}$ dan sianida total.

Ditimbang kebutuhan $\mathrm{Na}_{2} \mathrm{~S}_{2} \mathrm{O}_{5}$ (SMBS) dan $\mathrm{CuSO}_{4} .5 \mathrm{H}_{2} \mathrm{O}$ untuk volume tailing 15 liter. Tailing dengan volume 15 liter dimasukkan ke dalam reaktor SS-316 yang telah dilengkapi dengan agitator dan 2 buah aerator serta 1 buah detektor gas HCN. Reaktor dihidupkan, dimasukkan katalis $\mathrm{Cu}$ (II) dan $\mathrm{Na}_{2} \mathrm{~S}_{2} \mathrm{O}_{5}$ yang telah ditimbang, selanjutnya proses pengolahan dilakukan pada kondisi optimum yang telah diperoleh dari proses optimasi.

Di akhir proses, tailing hasil pengolahan diambil sampelnya untuk dianalisis konsentrasi sianida bebas, $\mathrm{CN}_{\mathrm{WAD}}$, sianida total dan logam berat. Preparasi sampel yang dilakukan adalah sama seperti preparasi pada tailing sebelum proses penghilangan sianida bebas.

Penelitian dilakukan di Laboratorium Pusat Teknologi Pengembangan Sumberdaya Mineral (PTPSM) Badan Pengkajian dan Penerapan Teknolgi (BPPT) - PUSPIPTEK.

\subsubsection{Analisis}

Sampel fasa cair tailing yang telah disaring dimasukkan ke dalam cuvet $10 \mathrm{ml}$ menggunakan pipet volumetri $10 \mathrm{~mL}$. Ke dalam sampel dimasukkan cyaniver 3 kemudian diaduk sampai terlarut, dibiarkan selama 30 detik, setelah itu ditambahkan cyaniver 4 sambil diaduk dan secepatnya ditambahkan cyaniver 5, diaduk kembali hingga terlarut. Pada spektrofotometer Hach DR2010 dipilih program 160, kemudian 
setting timer. Setelah 30 menit alat akan memberikan isyarat bunyi tiga kali, masukkan blanko (akuades) ke dalam alat kemudian tekan "zeroing". Layar digital pada alat akan menunjukkan angka 0,000 $\mathrm{mg} / \mathrm{L}$. Blangko dikeluarkan dari alat, selanjutnya sampel fasa cair tailing yang telah ditambah cyaniver 3,4 dan 5 dimasukkan, kemudian tekan "read". Konsentrasi sianida bebas dalam sampel ditunjukkan pada layar digital alat. Analisis sianida bebas tersebut menggunakan metode piridin pirazolon, warna biru yang terbentuk diukur pada panjang gelombang $520 \mathrm{~nm}$.

Analisis ekternal dilakukan di laboratorium Intertek dan ALS. Analisis tersebut untuk mengetahui kandungan sianida bebas, $\mathrm{CN}_{\mathrm{WAD}}$, total sianida serta logam berat pada fasa cairan dan fasa padatan tailing awal dan tailing setelah proses pengolahan. Preparasi sampel untuk kebutuhan analisa eksternal adalah sebagaimana yang telah diuraikan sebelumnya.

\subsection{Penentuan Kualitas Air Limbah}

Kualitas air limbah sebelum dan setelah proses pengolahan dianalisis secara deskriptif. Analisis dilakukan dengan membandingkan parameter hasil uji laboratorium terhadap parameter baku mutu sesuai Keputusan Menteri Negara Lingkungan Hidup No.202 Tahun 2004 ${ }^{(14)}$ (Tabel 2) dan status mutu air ditentukan menggunakan metode indeks pencemaran sesuai Keputusan Menteri Negara Lingkungan Hidup No.115 Tahun $2003^{(115)}$. Status mutu air merupakan tingkat kondisi mutu air yang menunjukkan kondisi cemar atau kondisi baik pada suatu sumber air dalam waktu tertentu dengan membandingkannya terhadap baku mutu yang ditetapkan ${ }^{(16)}$.

Tabel 2. Baku mutu air limbah bagi kegiatan pengolahan bijih emas ${ }^{(14)}$

\begin{tabular}{cccc}
\hline No & Parameter & Sat & Kadar Maksimum \\
\hline 1 & $\mathrm{pH}$ & - & $6-9$ \\
2 & $\mathrm{TSS}$ & $\mathrm{mg} / \mathrm{L}$ & 200 \\
3 & $\mathrm{Cu}$ & $\mathrm{mg} / \mathrm{L}$ & 2 \\
4 & $\mathrm{Cd}$ & $\mathrm{mg} / \mathrm{L}$ & 0,1 \\
5 & $\mathrm{Zn}$ & $\mathrm{mg} / \mathrm{L}$ & 5 \\
6 & $\mathrm{~Pb}$ & $\mathrm{mg} / \mathrm{L}$ & 1 \\
7 & $\mathrm{As}$ & $\mathrm{mg} / \mathrm{L}$ & 0,5 \\
8 & $\mathrm{Ni}$ & $\mathrm{mg} / \mathrm{L}$ & 0,5 \\
9 & $\mathrm{Cr}$ & $\mathrm{mg} / \mathrm{L}$ & 1 \\
10 & $\mathrm{CN}$ & $\mathrm{mg} / \mathrm{L}$ & 0,5 \\
11 & $\mathrm{Hg}$ & $\mathrm{mg} / \mathrm{L}$ & 0,005 \\
\hline
\end{tabular}

Sesuai dengan Keputusan Menteri Negara Lingkungan Hidup No.115 Tahun 2003 perhitungan indeks pencemaran dilakukan dengan menggunakan persamaan (1).
$P I j=\sqrt{\frac{\left(\frac{C i}{L i j}\right)^{2} M+\left(\frac{C i}{L i j}\right)^{2} R}{2}}$.

Di mana: $P I$ adalah indeks pencemaran bagi peruntukan $j$, Lij adalah konsentrasi parameter kualitas air yang dicantumkan dalam baku mutu, $\mathrm{Ci}$ adalah konsentrasi parameter kualitas air hasil pengukuran, (Cij/Lij)M adalah nilai Ci/Lij maksimum dan $(C i j / L i j) R$ adalah nilai $C i / L i j$ ratarata. Evaluasi nilai indeks pencemaran disajikan di dalam Tabel 3.

Tabel 3. Evaluasi nilai indeks pencemaran

\begin{tabular}{ccc}
\hline No & Indeks Pencemar & Mutu Perairan \\
\hline 1 & $0 \leq P i j \leq 1,0$ & Kondisi baik \\
2 & $1,0<\mathrm{Pij} \leq 5,0$ & Cemar ringan \\
3 & $5,0<\mathrm{Pij} \leq 10$ & Cemar sedang \\
4 & $\mathrm{Pij}>10$ & Cemar berat \\
\hline \multicolumn{2}{l}{ Sumber: KepmenLH No.115 Tahun $2003^{(15)}$}
\end{tabular}

\section{HASIL DAN PEMBAHASAN}

\subsection{Karakteristik tailing sianidasi}

Tailing sianidasi bijih emas Desa Lebak Situ Kecamatan Lebak Gedong Kabupaten Lebak Provinsi Banten dapat ditinjau dari karakteristik fisika dan kimia. Karakteristik fisikanya yaitu slurry dengan komposisi padatan sekitar 40\%, fasa padatnya berwarna putih-kuning dan fasa cairnya kuning keruh. Karakteristik kimiawinya dicirikan oleh pH slurry 10,3; konsentrasi sianida bebas, $\mathrm{CN}_{\text {WAD }}$ dan sianida total yang tinggi, baik dalam matriks padatan maupun dalam matriks cairan; namun konsentrasi logam beratnya seperti As, Cd, Cr, Cu, $\mathrm{Pb}, \mathrm{Hg}, \mathrm{Ni}$ dan $\mathrm{Zn}$ relatif kecil. Karakteristik tailing sianidasi bijih emas Desa Lebak Situ Kecamatan Lebak Gedong Kabupaten Lebak Provinsi Banten disajikan di dalam Tabel 4.

Konsentrasi sianida bebas dalam fasa cair tailing berada di atas baku mutu air limbah untuk kegiatan pengolahan emas sesuai Keputusan Menteri Negara Lingkungan Hidup No.202 Tahun 2004. Konsentrasi sianida bebas dalam fasa cair tailing adalah 95,8 mg/L lebih besar dibanding baku mutunya yaitu $0,5 \mathrm{mg} / \mathrm{L}$. Konsentrasi $\mathrm{CN}_{\text {WAD }}$ dan sianida total di dalam matrik cairan tailing berturut-turut adalah 147 dan $701 \mathrm{mg} / \mathrm{L}$. Konsentrasi sianida bebas, $\mathrm{CN}_{\mathrm{WAD}}$ dan sianida total di dalam matriks padatan tailing berturutturut 170; 242 dan 477 mg/L.

Konsentrasi logam berat dalam matriks cairan tailing relatif kecil dan ada di bawah baku mutu. Kondisi ini mengindikasikan bahwa (1) proses sianidasi yang dilakukan cukup selektif mengekstraksi emas dan perak, (2) logam berat yang dilepaskan dari proses sianidasi bijih emas Desa Lebak Situ Kecamatan Lebak Gedong 
Kabupaten Lebak Provinsi Banten tidak mempunyai dampak negatif yang signifikan terhadap lingkungan. Namun demikian kondisi ini sifatnya kasuistik dan tidak dapat digeneralisir.

Tabel 4. Hasil analisa tailing sianidasi bijih emas Desa Lebak Situ

\begin{tabular}{lccc}
\hline Parameter & Satuan & Hasil & Baku Mutu \\
\hline Padatan & & & - \\
\hline Sianida total & mg/dry kg & 477 & - \\
CN ${ }_{\text {WAD }}$ & mg/dry kg & 242 & - \\
Sianida bebas & mg/dry kg & 170 & - \\
\hline Cairan & & & - \\
\hline Sianida total & $\mathrm{mg} / \mathrm{L}$ & 701 & 0,5 \\
CN wAD $_{\text {Sianida bebas }}^{\mathrm{mg} / \mathrm{L}}$ & 147 & 0,5 \\
Arsenik $(\mathrm{As})$ & $\mathrm{mg} / \mathrm{L}$ & 95,8 & 0,1 \\
Kadmium $(\mathrm{Cd})$ & $\mathrm{mg} / \mathrm{L}$ & 0,017 & 1 \\
Kromium $(\mathrm{Cr})$ & $\mathrm{mg} / \mathrm{L}$ & $<0,001$ & 2 \\
Tembaga $(\mathrm{Cu})$ & $\mathrm{mg} / \mathrm{L}$ & 0,011 & 1 \\
Timbal $(\mathrm{Pb})$ & $\mathrm{mg} / \mathrm{L}$ & 0,044 & 0,005 \\
Merkuri $(\mathrm{Hg})$ & $\mathrm{mg} / \mathrm{L}$ & $<0,005$ & 0,5 \\
Nikel $(\mathrm{Ni})$ & $\mathrm{mg} / \mathrm{L}$ & $<0,0005$ & 5 \\
Seng $(\mathrm{Zn})$ & $\mathrm{mg} / \mathrm{L}$ & 0,109 &
\end{tabular}

Sumber: Hasil analisis Intertek dan ALS

Kandungan sianida total dan $\mathrm{CN}_{\text {WAD }}$ dalam matriks padatan dan cairan tailing yang tinggi berdampak pada peningkatan sianida bebas di lingkungan. $\mathrm{CN}_{\mathrm{WAD}}$ merupakan senyawa kompleks logam-sianida yang relatif mudah mengalami disosiasi di lingkungan menghasilkan sianida bebas. Sianida total mengandung $\mathrm{CN}_{\mathrm{SAD}}$ yaitu senyawa kompleks logam-sianida yang stabil sehingga relatif sulit terdisosiasi di lingkungan, namun seiring waktu $\mathrm{CN}_{\text {SAD }}$ dapat mengalami disosiasi ketika terpapar oleh sinar UV matahari menghasilkan sianida bebas. Cahaya UV menyebabkan kompleks logam seperti ferisianida dan ferrosianida terdisosiasi parsial, dalam kasus ini besi sianida terfotolisis menjadi sianida bebas dan besi hidroksida ${ }^{(3)}$.

Nilai $\mathrm{CN}_{\text {WAD }}$ dan sianida total yang tinggi pada fasa cairan tailing menunjukkan bahwa ada logam lain terlarutkan di dalam fasa cair tailing ${ }^{(13)}$. Logam lain tersebut kemungkinan besar adalah perak $(\mathrm{Ag})$ yang berkontribusi terhadap tingginya konsentrasi $\mathrm{CN}_{\text {WAD }}$ dan logam besi $(\mathrm{Fe})$ yang membentuk $\mathrm{CN}_{\mathrm{SAD}}$ serta berkontribusi terhadap tingginya konsentrasi sianida total pada tailing. Konsentrasi kedua logam tersebut tidak dianalisis karena tidak masuk kedalam parameter yang ada di dalam baku mutu yang telah ditetapkan.

\subsection{Proses pengolahan sianida}

\subsubsection{Pengaruh $\mathrm{pH}$}

Spesiasi sianida bebas dan gas sulfur $\left(\mathrm{SO}_{2}\right)$ di dalam air sangat dipengaruhi oleh $\mathrm{pH}$. Spesi $\mathrm{CN}^{-}$dari sianida akan dominan pada $\mathrm{pH}$ di atas 9,24 namun spesi $\mathrm{HCN}$ dari sianida akan dominan pada $\mathrm{pH}$ dibawah 9,24 . Nilai pKa dari sianida bebas ( $\mathrm{CN}^{-}$dan $\mathrm{HCN}$ ) adalah $9,24^{(9)}$. Spesi gas sulfur $\left(\mathrm{SO}_{2}\right)$ di dalam air akan berkesetimbangan dengan hidrogen sulfit dan bisulfit tergantung dari $\mathrm{pH}$ lingkungan. Pada $\mathrm{pH}$ di bawah 2 spesi yang dominan adalah $\mathrm{SO}_{2}$, pada $\mathrm{pH}$ antara 2,5-6,5 spesi yang dominan adalah hidrogen sulfit dan spesi bisulfit dominan pada $\mathrm{pH}$ di atas $8,5^{(17)}$.

Untuk mengetahui pengaruh $\mathrm{pH}$ terhadap proses penurunan sianida bebas dengan metode oksidasi dengan campuran gas sulfur dan oksigen terkatalisis tembaga (II), maka dilakukan percobaan pada variasi $\mathrm{pH} 8,0 ; 8,5$; 9,$0 ; 9,5 ;$ dan 10. Parameter lainnya adalah waktu pengolahan $1 \mathrm{jam}$, rasio $\mathrm{SO}_{2} / \mathrm{CN}^{-}(\mathrm{w} / \mathrm{w}) 4$, dosis katalis $\mathrm{Cu} 50 \mathrm{mg} / \mathrm{L}$, kelarutan oksigen 8 $\mathrm{mg} / \mathrm{L}$ dan pengadukan $500 \mathrm{rpm}$.

Hasil uji coba pengaruh $\mathrm{pH}$ pada penurunan konsentrasi sianida bebas yang diperoleh yaitu: pada $\mathrm{pH} 8$ dan 8,5 , konsentrasi sianida awal adalah $34 \mathrm{mg} / \mathrm{L}$ dan setelah proses pengolahan diperoleh konsentrasi sianida akhir berturut-turut $8 \mathrm{mg} / \mathrm{L}$ dan $9,7 \mathrm{mg} / \mathrm{L}$; pada $\mathrm{pH} \mathrm{9,} \mathrm{9,5} \mathrm{dan} 10$ konsentrasi sianida bebas awal adalah $43 \mathrm{mg} / \mathrm{L}$ dan setelah proses pengolahan diperoleh 
konsentrasi sianida bebas akhir berturut-turut 9,2 mg/L, 11,2 mg/L dan 16, mg/L. Berdasarkan hasil optimasi proses, pada $\mathrm{pH}$ pengolahan 9 diperoleh nilai persen penurunan konsentrasi sianida bebas terbesar yaitu $78,6 \%$.

Kondisi tersebut tidak terlepas dari proses kesetimbangan spesi gas $\mathrm{SO}_{2}$ di dalam air. Pada $\mathrm{pH}$ di sekitar 9, spesi yang dominan di dalam air adalah bisulfit $\left(\mathrm{SO}_{3}{ }^{-}\right)$. Dan hal ini sesuai juga dengan reagen yang digunakan yaitu sodium metabisulfit (SMBS). Ketika SMBS dilarutkan ke dalam air, maka reaksi pelarutan yang terjadi adalah sebagai berikut :

$$
\begin{aligned}
& \mathrm{Na}_{2} \mathrm{~S}_{2} \mathrm{O}_{5(\mathrm{~s})}+\mathrm{H}_{2} \mathrm{O}_{(\mathrm{l})} \rightarrow 2 \mathrm{Na}_{(\mathrm{aq})}^{+}+2 \mathrm{HSO}_{3}^{-}(\mathrm{aq}) \\
& 2 \mathrm{HSO}_{3}^{-}(\mathrm{aq}) \\
& +2 \mathrm{H}_{(\mathrm{aq})}^{+} \rightarrow 2 \mathrm{SO}_{2(\mathrm{~g})}+2 \mathrm{H}_{2} \mathrm{O}_{(\mathrm{l})}
\end{aligned}
$$

Spesi bisulfit dan oksigen yang terlarut mempunyai kemampuan mengoksidasi spesi $\mathrm{CN}^{-}$menjadi $\mathrm{OCN}^{-}$. Dengan demikian, $\mathrm{pH} 9$ merupakan $\mathrm{pH}$ optimum oksidasi spesi $\mathrm{CN}^{-}$ menjadi $\mathrm{OCN}^{-}$pada tailing sianidasi bijih emas dari lokasi Desa Lebak Situ Kecamatan Lebak Gedong Kabupaten Lebak Provinsi Banten dengan metode oksidasi menggunakan campuran gas sulfur dan oksigen terkatalisis tembaga (II).

\subsubsection{Pengaruh katalis}

Katalis yang digunakan di dalam proses penurunan sianida bebas dengan proses oksidasi menggunakan campuran gas $\mathrm{SO}_{2}$ dan $\mathrm{O}_{2}$ adalah tembaga (II). Variasi konsentrasi katalis yang diujicobakan yaitu 10, 25 50, 75 dan 100 mg/L. Parameter-parameter lainnya adalah $\mathrm{pH}$ pengolahan 9, waktu pengolahan 1 jam, rasio berat $\mathrm{SO}_{2} / \mathrm{CN}^{-} 4$, kelarutan oksigen $8 \mathrm{mg} / \mathrm{L}$ dan pengadukan $500 \mathrm{rpm}$. Gambar 2.b memperlihatkan hubungan antara penurunan konsentrasi sianida bebas (\%) terhadap dosis katalis $\mathrm{Cu}(\mathrm{II})$ berdasarkan hasil percobaan.

Hasil percobaan pengaruh konsentrasi katalis $\mathrm{Cu}(\mathrm{II})$ terhadap penurunan konsentrasi sianida bebas yaitu: pada konsentrasi katalis $\mathrm{Cu}(\mathrm{II})$ 10, 25 ,50, 75 dan $100 \mathrm{mg} / \mathrm{L}$ konsentrasi sianida bebas awal adalah $39 \mathrm{mg} / \mathrm{L}$ dan setelah proses pengolahan diperoleh konsentrasi sianida bebas akhir berturut-turut 9,$1 ; 7,6 ; 6,2$; 5 dan $7,7 \mathrm{mg} / \mathrm{L}$.

Berdasarkan hasil optimasi, penurunan konsentrasi sianida bebas di dalam tailing meningkat seiring dengan bertambahnya dosis katalis $\mathrm{Cu}(\mathrm{II})$ yaitu dari $10-75 \mathrm{mg} / \mathrm{L}$. Namun pada dosis katalis $\mathrm{Cu}(\mathrm{II}) \quad 100 \mathrm{mg} / \mathrm{L}$ persen pengurangan konsentrasi sianida bebas cenderung menurun hal ini kemungkinan disebabkan oleh proses disosiasi kompleks logam-sianida lemah $\left(\mathrm{CN}_{\mathrm{WAD}}\right)$ menjadi sianida bebas. Dosis katalis Cu(II) $75 \mathrm{mg} / \mathrm{L}$ merupakan dosis optimum katalis yang diperoleh karena pada dosis tersebut terjadi pengurangan konsentrasi sianida bebas di dalam limbah yang tertinggi yaitu dengan persen penurunan $87.18 \%$.

\subsubsection{Pengaruh waktu}

Percobaan pengaruh waktu terhadap penurunan konsentrasi sianida bebas dilakukan pada variasi waktu 1, 2, 3, 4 dan 5 jam. Parameter lain yang digunakan adalah $\mathrm{pH}$ pengolahan 9 , rasio berat $\mathrm{SO}_{2} / \mathrm{CN}^{-} 4$, dosis katalis Cu (II) $75 \mathrm{mg} / \mathrm{L}$, kelarutan oksigen $8 \mathrm{mg} / \mathrm{L}$ dan pengadukan $500 \mathrm{rpm}$.

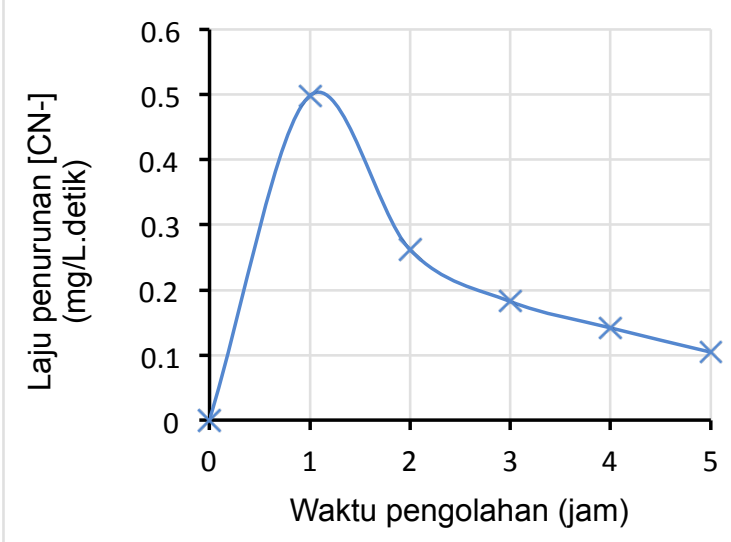

Gambar 1. Hubungan laju penuruna konsentrasi sianida bebas terhadap waktu pengolahan

Laju penurunan konsentrasi sianida bebas terhadap waktu pada proses penghilangan dengan metode oksidasi menggunakan campuran gas sulfur dan oksigen terkatalisis tembaga (II) disajikan di dalam Gambar 1.

Hasil percobaan pengaruh waktu terhadap penurunan konsentrasi sianida bebas menunjukkan bahwa seiring dengan bertambahnya waktu yaitu dari 1-4 jam, maka penurunan konsentrasi sianida bebas juga meningkat yaitu berturut-turut dari $76,67 \%$, $80,51 \%, 84,1 \%$ dan $87,1 \%$. Namun ketika waktu ditambah hingga jam ke-5, penurunan konsentrasi sianida bebas turun menjadi $80,26 \%$. Kondisi yang terjadi pada jam ke-5 tersebut kemungkinan terjadi sebagai akibat dari laju penurunan konsentrasi sianida bebas yang semakin rendah sementara itu laju disosiasi kompleks logam-sianida lemah ( $\left.\mathrm{CN}_{\mathrm{WAD}}\right)$ menjadi sianida bebas meningkat. $\mathrm{Hal}$ ini juga mengindikasikan bahwa jumlah gas $\mathrm{SO}_{2}$ di dalam limbah tidak mencukupi untuk 
mengoksidasi sianida bebas yang terbentuk dari proses disosiasi $\mathrm{CN}_{\text {WAD }}$ menjadi sianat. Data sebelumnya menunjukkan bahwa senyawa kompleks lemah dari logam-sianida ( $C N_{\text {WAD }}$ ) pada limbah sianidasi bijih emas Desa Lebak Situ adalah $147 \mathrm{mg} / \mathrm{L}$.

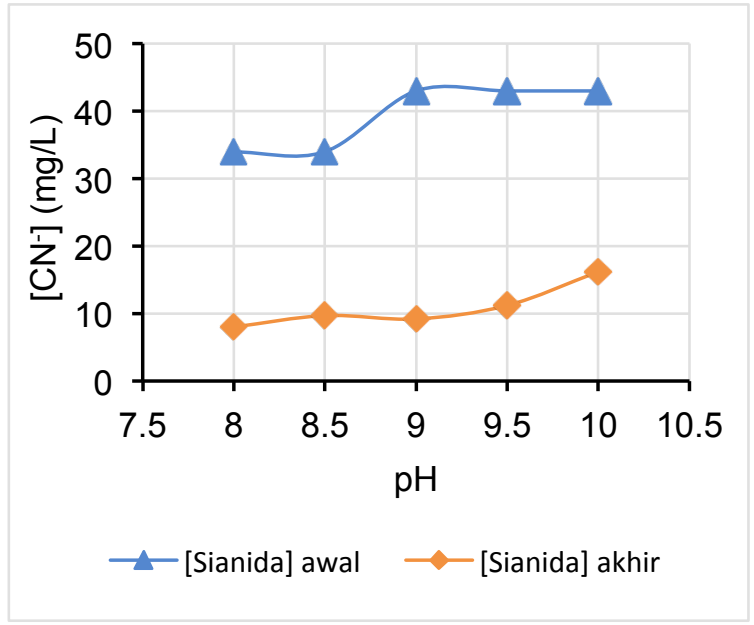

(a)

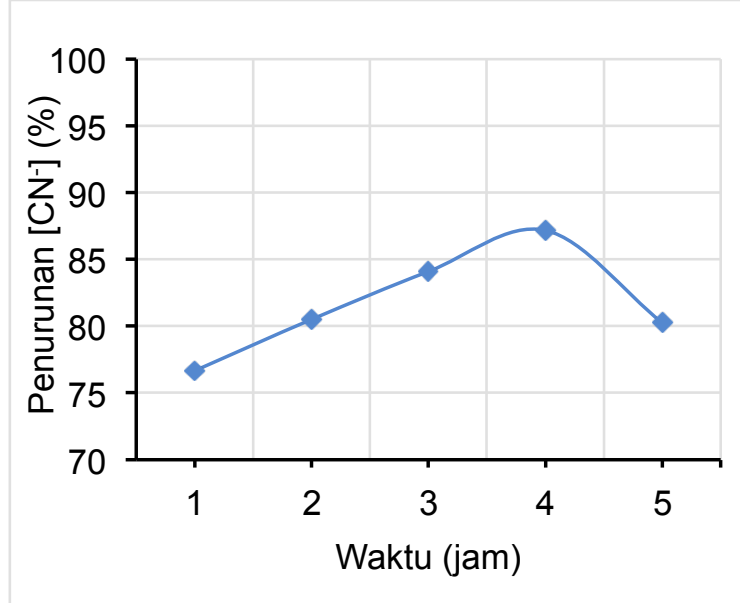

(c)
Grafik hubungan antara penurunan konsentrasi sianida bebas dalam tailing terhadap $\mathrm{pH}$, konsentrasi katalis $\mathrm{Cu}(\mathrm{II})$, waktu dan rasio berat $\mathrm{SO}_{2} / \mathrm{CN}^{-}$disajikan di dalam Gambar 2.

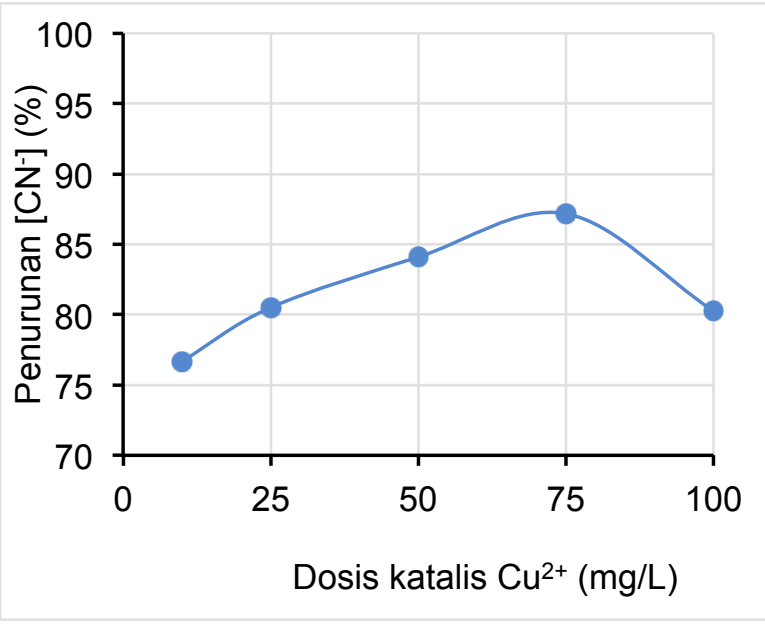

(b)

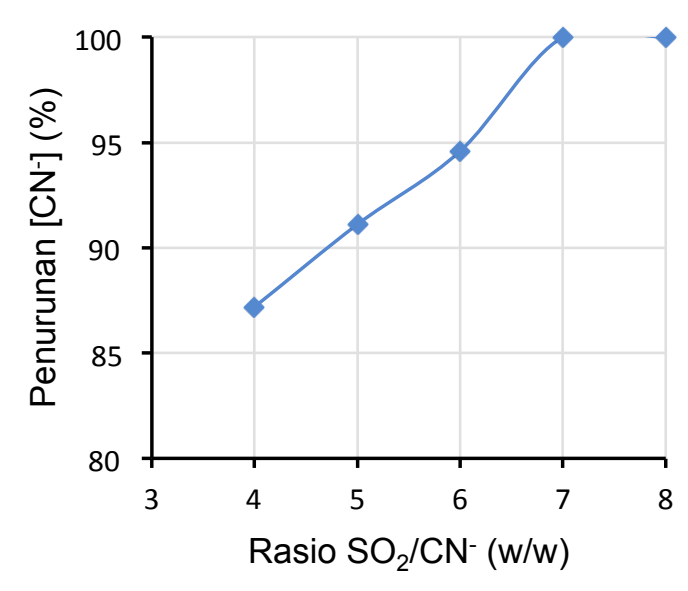

(d)

Gambar 2. Penurunan konsentrasi sianida bebas pada optimasi proses, hubungan antara konsentrasi sianida terhadap $\mathrm{pH}(\mathrm{a})$, dosis katalis $\mathrm{Cu}^{2+}(\mathrm{b})$, waktu (c) dan rasio $\mathrm{SO}_{2} / \mathrm{CN}^{-}(\mathrm{d})$.

\subsubsection{Pengaruh rasio berat $\mathrm{SO}_{2} / \mathrm{CN}^{-}$}

Rasio berat $\mathrm{SO}_{2} / \mathrm{CN}^{-}$sangat signifikan dalam proses detoksifikasi sianida bebas dalam tailing. Semakin tinggi nilai rasio $\mathrm{SO}_{2} / \mathrm{CN}^{-}(\mathrm{w} / \mathrm{w})$ artinya semakin banyak material sumber gas $\mathrm{SO}_{2}$ yang dibutuhkan. Pada kegiatan uji coba ini sumber $\mathrm{SO}_{2}$ yang digunakan adalah natrium metabisulfit $\left(\mathrm{Na}_{2} \mathrm{~S}_{2} \mathrm{O}_{5}\right)$. Gas $\mathrm{SO}_{2}$ yang dihasilkan dari natrium metabisulfit bersama-sama dengan oksigen yang terlarut secara berturut-turut akan mengoksidasi sianida bebas dalam tailing menjadi sianat $\left(\mathrm{CNO}^{-}\right)$dan memecah ikatan kompleks logam-sianida lemah ( $\left.\mathrm{CN}_{\mathrm{WAD}}\right)$ menjadi sianida bebas seperti pada reaksi (1). Toksisitas sianat ( $\mathrm{CNO}^{-}$) sebagai spesi yang dihasilkan dari proses oksidasi sianida bebas adalah 1000 kali lebih rendah dibandingkan sianida bebas ${ }^{(3)}$.

Rasio berat $\mathrm{SO}_{2} / \mathrm{CN}^{-}$yang digunakan dalam percobaan adalah rasio 4, 5, 6, 7 dan 8. Secara teoretis rasio berat konsumsi $\mathrm{SO}_{2}$ terhadap $\mathrm{CN}^{-}$ WAD adalah $2,46^{(3)}$. Rasio yang digunakan dalam percobaan ini lebih besar dibandingkan dengan rasio secara teoretis karena didasarkan pada perbandingan berat gas belerang terhadap berat sianida bebas dan bukan terhadap berat $\mathrm{CN}_{\mathrm{WAD}}$. 
Hasil yang diperoleh menunjukkan bahwa semakin besar nilai rasio berat $\mathrm{SO}_{2} / \mathrm{CN}^{-}$maka akan semakin besar persen penurunan sianida bebasnya. Penurunan konsentrasi sianida bebas pada rasio berat $\mathrm{SO}_{2} / \mathrm{CN}^{-}$sebesar 4 adalah $87,18 \%$ dimana konsentrasi sianida bebas turun dari $39 \mathrm{mg} / \mathrm{L}$ menjadi $5 \mathrm{mg} / \mathrm{L}$. Penurunan konsentrasi sianida bebas pada rasio berat $\mathrm{SO}_{2} / \mathrm{CN}^{-}$sebesar 5 adalah $91,11 \%$ dimana konsentrasi sianida bebas turun dari 45 $\mathrm{mg} / \mathrm{L}$ menjadi $4 \mathrm{mg} / \mathrm{L}$. Penurunan konsentrasi sianida bebas pada rasio berat $\mathrm{SO}_{2} / \mathrm{CN}^{-}$sebesar 6 adalah 94,59\% dimana konsentrasi sianida bebas turun dari $37 \mathrm{mg} / \mathrm{L}$ menjadi $2 \mathrm{mg} / \mathrm{L}$. Pada rasio berat $\mathrm{SO}_{2} / \mathrm{CN}^{-}$sebesar 7 dan 8 , penurunan konsentrasi sianida bebas yang terjadi adalah $100 \%$. Rasio berat $\mathrm{SO}_{2} / \mathrm{CN}^{-}$sebesar 7 dan 8 sepertinya mampu menyediakan gas $\mathrm{SO}_{2}$ dengan cukup untuk mengoksidasi sianida bebas dan $\mathrm{CN}_{\text {WAD }}$ pada limbah menjadi sianat. Dengan mempertimbangkan keefektifan dan efisiensi proses, maka rasio berat $\mathrm{SO}_{2} / \mathrm{CN}^{-}$ sebesar 7 ditetapkan sebagai rasio optimum pengolahan.

\subsection{Uji aplikasi}

Uji aplikasi merupakan uji coba proses pengolahan dengan menerapkan parameter pengolahan optimum yang diperoleh dari uji coba optimasi pengolahan dengan memperbesar skala operasinya. Oleh karena itu, uji aplikasi merupakan lanjutan dari proses optimasi parameter-parameter pengolahan. Parameter pengolahan yang diperoleh dari proses optimasi dan diterapkan selama uji aplikasi adalah $\mathrm{pH}$ pengolahan 9, dosis katalis $\mathrm{Cu}$ (II) $75 \mathrm{mg} / \mathrm{L}$, waktu pengolahan 4 jam dan rasio berat $\mathrm{SO}_{2} / \mathrm{CN}^{-}$sebesar 7 . Sementara itu parameter lainnya adalah volume limbah 15 liter; kecepatan pengadukkan $350 \mathrm{rpm}$, kelarutan oksigen $\pm 8 \mathrm{mg} / \mathrm{L}$ dan dilakukan pada temperatur ruang.

Konsentrasi pencemar dalam tailing selama proses uji aplikasi mengalami penurunan. Sianida total, $\mathrm{CN}_{\text {WAD }}$ dan sianida bebas pada matriks padatan tailing dari 477; 242 dan 170 $\mathrm{mg} / \mathrm{L}$ secara berturut-turut turun menjadi 1,25 ; 2,36 dan dan $1,3 \mathrm{mg} / \mathrm{L}$. Sianida total, $\mathrm{CN}_{\text {WAD }}$ dan sianida bebas pada matriks cairan tailing dari 701; 147 dan 95,8 mg/L secara berturut-turut turun menjadi 0,$270 ; 0,46$ dan $0,25 \mathrm{mg} / \mathrm{L}$. Konsentrasi logam berat $\mathrm{As}, \mathrm{Ni}$ dan $\mathrm{Zn}$ mengalami penurunan walaupun tidak signifikan sementara konsentrasi logam berat $\mathrm{Cd}, \mathrm{Cr}, \mathrm{Pb}$ dan $\mathrm{Hg}$ relatif konstan namun untuk konsentrasi logam Cu mengalami kenaikan dari $0,044 \mathrm{mg} / \mathrm{L}$ menjadi 0,062 $\mathrm{mg} / \mathrm{L}$. Kenaikan yang terjadi pada konsentrasi logam $\mathrm{Cu}$ diakibatkan karena ada penambahan konsentrasi dari katalis $\mathrm{Cu}(\mathrm{II})$.

Uji aplikasi pengolahan telah mampu menurunkan parameter-parameter pencemar yang dianalisis sehingga masuk Baku Mutu lingkungan limbah cair untuk proses pengolahan bijih emas sesuai Keputusan Menteri Negara Lingkungan Hidup No.202 Tahun 2004. Parameter-parameter yang dianalisa sesuai peraturan tersebut adalah sianida bebas $\left(\mathrm{CN}^{-}\right)$ dan logam terlarut tembaga (Cu), cadmium (Cd), seng $(\mathrm{Zn})$, timbal $(\mathrm{Pb})$, arsenik (As), nikel $(\mathrm{Ni})$, kromium $(\mathrm{Cr})$ dan merkuri $(\mathrm{Hg})$. Parameter yang tidak dianalisis dan sesuai dengan peraturan tersebut adalah $\mathrm{pH}$ dan total padatan tersuspensi atau TSS. Namun demikian, secara kualitatif parameter tersebut dapat masuk Baku Mutu yang ditetapkan karena: (1) proses pengolahan dilakukan pada $\mathrm{pH} 9$ dan selama proses berlangsung cenderung menurun karena terbentuk asam sulfat yang kemudian dinetralkan dengan penambahan basa, dan (2) limbah hasil pengolahan dengan proses oksidasi-presipitasi ini setelah diendapkan fasa cairnya relatif jernih. Baku mutu untuk pH dan total padatan tersuspensi atau TSS sesuai peraturan tersebut secara berturut-turut adalah 6-9 dan $200 \mathrm{mg} / \mathrm{L}$. Hasil uji aplikasi pengolahan limbah sianidasi bijih emas dari Desa Lebak Situ Kecamatan Lebak Gedong Kabupaten Lebak dengan proses oksidasi-presipitasi menggunakan campuran gas $\mathrm{SO}_{2}$-udara $\left(\mathrm{O}_{2}\right)$ terkatalisis $\mathrm{Cu}$ (II) dan perbandingannya dengan Baku Mutu pengolahan emas sesuai Keputusan Menteri Negara Lingkungan Hidup No.202 Tahun 2004 disajikan di dalam Tabel 5.

\subsection{Penentuan status mutu air}

Kualitas suatu perairan dapat ditinjau dari nilai indeks pencemarannya. Semakin tinggi nilai indeks pencemaran, maka kondisi perairan tersebut semakin tercemar. Nilai Indeks pencemaran air sebelum proses penghilangan sianida bebas adalah 136,32 yang berarti kondisi air tersebut tercemar berat dan setelah proses penghilangan sianida bebas adalah 0,36 yang berarti kondisi airnya baik ${ }^{(15)}$. 
Tabel 5. Hasil uji aplikasi pengolahan limbah sianidasi bijih emas Lebak Situ oleh gas sulfur-oksigen terkatalis $\mathrm{Cu}(\mathrm{II})$ dan perbandingannya dengan Baku Mutu

\begin{tabular}{|c|c|c|c|c|}
\hline \multirow{2}{*}{ Parameter } & \multirow{2}{*}{ Satuan } & \multicolumn{2}{|c|}{ Hasil } & \multirow{2}{*}{ Baku Mutu } \\
\hline & & Sebelum & Sesudah & \\
\hline \multicolumn{5}{|l|}{ Matriks padat } \\
\hline Sianida total & $m g / d r y ~ k g$ & 477 & 1,25 & -- \\
\hline $\mathrm{CN}_{\text {WAD }}{ }^{*}$ & $m g / d r y ~ k g$ & 242 & 2,36 & -- \\
\hline Sianida bebas ${ }^{*}$ & $m g / d r y k g$ & 170 & 1,30 & -- \\
\hline \multicolumn{5}{|l|}{ Matriks cair } \\
\hline Sianida total & $\mathrm{mg} / \mathrm{L}$ & 701 & 0,270 & -- \\
\hline $\mathrm{CN}_{\text {WAD }}{ }^{*}$ & $\mathrm{mg} / \mathrm{L}$ & 147 & 0,460 & -- \\
\hline Sianida bebas ${ }^{*}$ & $\mathrm{mg} / \mathrm{L}$ & 95,8 & 0,250 & 0,5 \\
\hline Arsenik (As) & $\mathrm{mg} / \mathrm{L}$ & 0,017 & 0,015 & 0,5 \\
\hline Kadmium (Cd) & $\mathrm{mg} / \mathrm{L}$ & $<0,001$ & $<0,001$ & 0,1 \\
\hline Kromium (Cr) & $\mathrm{mg} / \mathrm{L}$ & 0,011 & 0,011 & 1 \\
\hline Tembaga (Cu) & $\mathrm{mg} / \mathrm{L}$ & 0,044 & 0,062 & 2 \\
\hline Timbal (Pb) & $\mathrm{mg} / \mathrm{L}$ & $<0,005$ & $<0,005$ & 1 \\
\hline Merkuri (Hg) & $\mathrm{mg} / \mathrm{L}$ & $<0,0005$ & $<0,0005$ & 0,005 \\
\hline Nikel (Ni) & $\mathrm{mg} / \mathrm{L}$ & 0,109 & 0,018 & 0,5 \\
\hline Seng $(Z n)^{* *}$ & $\mathrm{mg} / \mathrm{L}$ & 0,013 & 0,012 & 5 \\
\hline
\end{tabular}

Sumber: Hasil analisis Intertek (") dan ALS ()

Parameter yang paling dominan pengaruhnya terhadap besarnya nilai indeks pencemaran tersebut adalah konsentrasi sianida bebas. Konsentrasi sianida bebas pada limbah atau tailing sebelum proses pengolahan adalah $95,8 \mathrm{mg} / \mathrm{L}$ dan setelah proses pengolahan turun menjadi $0,25 \mathrm{mg} / \mathrm{L}$. Sementara itu, baku mutu untuk konsentrasi sianida bebas adalah 0,5 $\mathrm{mg} / \mathrm{L}$. Adapun konsentrasi logam berat terlarut pada tailing sebelum pengolahan dan setelah pengolahan tidak mengalami perubahan signifikan. Status mutu air limbah sebelum dan setelah proses pengolahan disajikan di dalam Tabel 6.

Tabel 6. Kualitas air sebelum dan setelah proses pengolahan

\begin{tabular}{cccc}
\hline No & $\begin{array}{c}\text { Sampel } \\
\text { Air }\end{array}$ & $\begin{array}{c}\text { Indeks } \\
\text { Pencemaran }\end{array}$ & Mutu Perairan \\
\hline 1 & Sebelum & 136,32 & Cemar berat \\
\hline 2 & Setelah & 0,36 & Kondisi baik \\
\hline
\end{tabular}

\section{KESIMPULAN}

Parameter optimum proses untuk menurunkan konsentrasi sianida bebas pada air limbah pengolahan emas dari bijih yang berasal dari Desa Lebak Situ Kecamatan Lebak Gedong Kabupaten Lebak dengan oksidasi-presipitasi menggunakan campuran gas belerang dan oksigen terkatalisis tembaga (II) adalah rasio berat $\mathrm{SO}_{2} / \mathrm{CN}^{-}$sebesar 7 ; dosis katalis $75 \mathrm{mg} / \mathrm{L}$; $\mathrm{pH}$ pengolahan 9 dan waktu pengolahan 4 jam. Uji aplikasi yang dilakukan dengan menggunakan parameter-parameter optimum tersebut telah mampu menurunkan konsentrasi sianida bebas pada matriks padatan dan matriks cairan berturut-turut dari $170 \mathrm{mg} / \mathrm{L}$ dan 95,8 $\mathrm{mg} / \mathrm{L}$ menjadi $1,3 \mathrm{mg} / \mathrm{L}$ dan $0,25 \mathrm{mg} / \mathrm{L}$. Parameter pencemar pada air limbah hasil pengolahan yaitu konsentrasi sianida bebas dan konsentrasi logam berat $\mathrm{As}, \mathrm{Cd}, \mathrm{Cr}, \mathrm{Cu}, \mathrm{Pb}, \mathrm{Hg}$, $\mathrm{Ni}$ dan $\mathrm{Zn}$ telah memenuhi Baku Mutu limbah cair proses pengolahan bijih emas. Nilai indeks cemaran air sebelum pengolahan adalah 136,32 yang artinya air tercemar berat, dan nilai indeks cemaran air setelah pengolahan adalah 0,36 yang artinya air dalam kondisi baik. Penurunan konsentrasi sianida bebas dan nilai indeks cemaran yang signifikan menunjukkaa bahwa proses oksidasi-presipitasi menggunakan gas sulfur dan oksigen terkatalisis tembaga (II) cukup efektif dalam mengolahan limbah sianida pada pertambangan emas skala kecil.

\section{PERSANTUNAN}

Kami sampaikan terima kasih kepada semua pihak yang telah memberikan kontribusi pada kegiatan penelitian ini, khususnya Ir. Adelin Setiabudi, M.Eng selaku chief enggineer dan Ir. Dadan M Nurjaman, M.T selaku Direktur Pusat Teknologi Pengembangan Sumberdaya Mineral BPPT atas bimbingan dan arahannya. Kegiatan penelitian ini dibiayai oleh dana DIPA PTPSM 2017.

\section{DAFTAR PUSTAKA}

1. Mekuto, L., Ntwampe, S.K.O., Akcil, A. (2016). An Integrated Biological Approach for Treatment of Cyanidation Wastewater. Sci. Total Environ, 571, 711-720 
2. Ritcey, G.M. (2005). Tailing Management in Gold Plants. Hydrometallurgy, 78, 3-20

3. Kuyucak, N., Akcil, A. (2013). Cyanide and Removal Options from Effluents in Gold Mining and Metallurgical Processes. Miner. Eng, 50-51, 13-29

4. Siller, H., Winter, J. (1998). Degradation of Cyanide in Agroindustrial or Industrial Wastewater in an Acidification Reactor or in a Single-step Methane Reactor by Bacteria Enriched from Soil and Peels of Cassava. Appl. Microbiol. Biotechnol, 50, 384-389

5. Nurohmat, A. (2016). Adorpsi Sianida dalam Air pada Mg/Al Hidrotalsit. Tesis. FMIPA UGM Yogyakarta

6. Razanamahandry, L. C., Andrianisa, H. A., Keroui, H., Kouakou, K. M., Yacouba, H. (2016). Biodegradation of free cyanide by bacterial species isolated from cyanidecontaminated artisanal gold mining catchment area in Burkina Faso, Chemosphere., 157, 71-78

7. Rader, W. S., Solujic, L., Milosavljevic, E. B., Hendrix, J, L., Nelson, J. H. (1995). Photocatalytic detoxification of cyanide and metal cyano-species from preciuous-metal mill effluents, Environ. Pollut., 90, 331-334

8. Dash, R. R., Balomajumder, C., Kumar, A. (2009). Removal of cyanide from water and wastewater using granular activated carbon, Chem. Eng. J., 146, 408-413

9. Kitis, M., Akcil, A., Karakaya, E., Yigit, N. O. (2004). Destruction of cyanide by hydrogen peroxide in tailing slurries from low bearing sulphidic gold ore, Miner. Eng., 18, 353-362

10. Saarela, K., Kuokkanen, T. (2004). Alternative disposal methods for wastewater containing cyanide: analytical methods for new electrolysis technology developed for total treatment of wastewater containing gold or silver cyanide. In: Pongracz, E. (Ed.), Proceedings of the Waste Minimization and Resource Use Optimization Conference, June 10, 2004. University of Oulu, Oulu Finland

11. Nelson, G.M., Kroeger, E.B., Arps, P.J. (1998). Chemical and biological destruction of cyanide: comparative costs in a cold climate, Miner. Process. Extr. Metall. Rev, 19, 217-226

12. Maimekov, Z.K., Sambaeva, D.A., Kemelov, K.A., Moldobaev, M.B., Izakov, J. B. (2014). Destruction of Sodium Cyanide and Determination of Hydrogen Index of the Industrial Waste Water, Journal of The Institute of Natural \& Applied Sciences, 19 (1-2):25-29

13. Dzombak, D. A., Ghosh, R. S., WongChong, G. M. (2006). Cyanide in Water and Soil, Chemistry, Risk, and Management, CRC Press, Boca Raton

14. Pemerintah Republik Indonesia. (2004). Keputusan Menteri Negara Lingkungan Hidup No.202 Tahun 2004 tentang Baku Mutu Air Limbah untuk Usaha dan atau Kegiatan Pertambangan Bijih Emas dan Atau Tembaga. Jakarta, Sekretariat Negara

15. Pemerintah Republik Indonesia. (2003). Keputusan Menteri Negara Lingkungan Hidup No. 115 Tahun 2003 tentang Pedoman Penentuan Status Mutu Air. Jakarta, Sekretariat Negara.

16. Djoharam, V., Riani, E., Yani, M. (2018). Analisis Kualitas Air dan Daya Tampung Beban Pencemaran Sngai Pesanggrahan di Wilayah Provinsi DKI Jakarta. Jurnal pengelolaan sumberdaya alam dan lingkungan, 8, 1 (127-133)

17. Guido, L. F. (2016). Sulfite in Beer: Reviewing Regulations, Analysis and Role. Sci. Agric 